\title{
The Institution of Community Custodians of Heritage Sites as an Element of Historic Asset Protection System. The Case of Poland
}

\author{
Dominika HOŁUJ ${ }^{*_{1}}$ \\ *Corresponding author \\ ${ }^{1}$ Cracow University of Economics, College of Public Economy and Administration, Institute of Spatial Development and Urban \\ Studies, Cracow, POLAND \\ E-mail: holujd@uek.krakow.pl \\ DOI: 10.24193/JSSP.2019.2.07 \\ https://doi.org/10.24193/JSSP.2019.2.07
}

K e y w o r d s: heritage management, social participation, participative administration model, cultural heritage, community heritage custodianship, volunteers, local community, Poland

\begin{abstract}
A B S T RA C T
Developing the participative model of heritage management is today one of the most frequently addressed issues in the scholarly debates on social participation. Volunteers are the core element of this model. The article contains an analysis of the factors determining the degree of development of the participatory system in Poland, i.e. the use of volunteers as community custodians, who have a range of legally appointed duties connected with preserving heritage and its values. The paper is a contribution to the international debate on the factors that have a role in the development of participatory heritage management and the benefits of this form of heritage management. The hypothesis is that creating a fuller legal framework for community care of heritage sites could constitute a valuable supplement to the core system of heritage protection and benefit both the sites and the public services, but also, in a wider context, other projects involving volunteers. Factorial analysis facilitated the identification of the main determinants of volunteers' actions in this area. The major factors hampering the work of volunteer participants in such projects in Poland are the lack of legal and organizational structure regulating their work, which gives rise to issues such as a lack of stable funding, failure to define long-term objectives for action and cooperation between custodians and authorities, and the insufficiency of existing legal instruments for ascertaining, monitoring, and developing custodians' knowledge on cultural heritage. The negative impact of these factors could be mitigated by changes in regulations and modification of relations between authorities and community. The challenge for further research is to develop more precise ways of examining the impact of work done by community custodians, something which is currently impossible due to the underdevelopment of the system for reporting on their work.
\end{abstract}

\section{INTRODUCTION}

Public spaces are forums for development features that have a diverse range of uses for both society and economy. These include cultural heritage resources such as heritage sites. This endogenous potential derives its usefulness for the well-being of the community and local economy from the social and economic values that heritage represents. A community's bond with its heritage renders it as one of the rightful stakeholders in heritage management. The development of participative forms of heritage management has increasingly been recognized as important because it brings benefits to heritage assets, local communities, and authorities alike, as described in the successive sections of this article. In the context of 
heritage values mentioned above, and its importance in and for society, this study describes and analyses one particular legal form of community involvement in heritage management: community custodians. The aim of this research is to detail the factors in the development of the participatory system of heritage management in respect of the use of volunteers with the status of community custodian (hereinafter referred to as "CC"). To date, there has been no description or analysis on the international forum of either the Polish legal formula for the functioning of community custodians or the organization of cooperation between community custodians and the Polish authorities. Factorial analysis has been indicated in previous scientific studies as an appropriate method for analysing this subject. In the results and discussion sections of the article the observations made in the process of analysing the Polish modus operandi are first described and subsequently compared with selected solutions practiced in the European countries, where the participatory system of heritage management engaging volunteers is well developed.

The achievement of the aim of the study as formulated above will broaden the awareness on the problems related to the implementation of participative models of heritage management. Even though many determinants are strongly influenced by local factors and circumstances, some are also found in other case studies. Therefore, the results of this Polish case study may prove important not only for work to improve the Polish heritage management system, but also for efforts to broaden both theoretical and practical knowledge on a wider scale, as is suggested in the conclusion section. The results of the analysis may be of particular importance for countries with underdeveloped social participation resulting from historical conditions, and countries in which the legal environment and the culture of cooperation between the authorities and social activists are underdeveloped.

\section{THEORY AND METHODOLOGY}

Cultural heritage represents everything that people want to preserve, anything that is of value to a person or a group, whether tangible or intangible, such as symbolic meanings, rituals, and traditions, which are often linked to specific places (Council of Europe, 2005; Smith, 2006; Howard, 2009; CHCfE Consortium, 2015; United Nations, 2017). The values assigned to heritage may be connected with aspects of identity such as nationality, religion, ethnicity, class, wealth, gender, and personal history (Graham and Howard, 2012). It is these values that transform history into heritage (Ashworth, 1994). The many dimensions of the cultural value of heritage include the aesthetic, the spiritual, the social (creating bonds within a society), the historical, and the symbolic, as well as the quality of authenticity
(Throsby, 2002). Heritage values are assigned by a variety of stakeholders, including the resource owner, the local community (the successors to the cultural achievements that contribute to their cultural identity), public services (including conservation authorities), and businesses. It is therefore possible to identify a range of perspectives from which socio-economic values are assigned to heritage, and three dimensions of broadly defined "ownership" of the resource. Ownership here is understood to mean not only the legal title in the strict sense of the term (i.e. legal possession of the resource), but also the sense of belonging that is fostered by the cultivation of a social bond with the resource, meeting the human need to provide protection and guardianship and accept voluntary responsibility (local community "ownership"). In this context it is the public institutions that are responsible for facilitating the long-term, sustainable use of heritage resources, so they can be referred to as "standards supervisors" in heritage management. This article focuses on the relationship between the local community and its heritage assets, and analyses the Polish legal solution of appointing CCs. These collaborate with the public services (and owners) and take care of heritage assets on a voluntary basis, functioning in the role of long-term volunteers formally appointed by the relevant authorities.

The principal act of law regulating the activity of CCs is the Heritage Protection and Care Act of 23 July 2003. Articles 102 and 104 set forth the duties and responsibilities of CCs: to promote the values represented by the given heritage asset, and to maintain the heritage asset in the best condition possible, as well as to promote awareness of the heritage it represents. CCs are authorised to admonish those violating the above law. The legislation stipulates that CCs should perform their work in collaboration with the Voivodship Heritage Conservation Officer and the poviat [district] council. Pursuant to the Heritage Protection and Conservation Act, any individual can serve as a CC as long as they are physically and mentally able, have a clean criminal record, and are knowledgeable in the field of heritage protection or conservation. Organizations can also be appointed CCs, in which case it is the members of their managerial staff who are verified in respect of the above requirements. Practice shows that most such entities are nongovernmental organizations with a heritage and historical focus.

The importance of developing a participative heritage management system has been recognized by scientists, politicians, and practitioners (Irvin and Stansbury, 2004; Macdonald, 2011; Purchla, 2012; CHCfE Consortium, 2015; Pendlebury, 2015; European Union, 2018; Vahtikari, 2019). Previous studies of the practical aspects of implementing participation in the heritage management system (e.g. in Scandinavian countries, England, Germany, and Italy) have 
individualized a catalogue of the most significant actions taken in this area. This includes monument adoption projects; implementation of new functions for historic sites and areas; voluntary work for cultural institutions; gathering and dissemination of knowledge about specific objects or groups of objects (in the form of book and press publications, above all local titles); creation of archives, including oral history archives and photographic documentation; digitization of archives; and organization of events, lessons, workshops, and exhibitions in or about heritage assets) (Chambers, 2002; Kling, 2010; Bauer et al., 2011; Fristrup et al., 2012; Zipsane, 2012; Stebbins, 2015). Previous research into the implementation of this model has demonstrated the importance of ensuring that if appropriate policies are put in place and legal solutions are enacted it would allow both the assets and the volunteers caring for them to benefit from their heritage status. Among the factors that have the potential to improve the condition of heritage environment are the law (on participation in cultural heritage management), the funding (for events and projects), and the institutional support (for heritage societies and professionals who are supportive and willing to undertake more extensive cooperation with community actors). Involving the wider society on a regular, continuous basis is crucial. Establishing and acknowledging the expectations of all stakeholders involved, articulating clearly the reach and aims of action, and raising community awareness of any areas where knowledge on heritage is lacking (and securing the willingness to accept professional support) are essential elements of the process (The Heritage Council, 2000; The Nordic Centre of Heritage Learning, 2012; Mannarini and Talò, 2013; Christidou and Hansen, 2015; European Union, 2018; Häyrynen, 2018). Moreover, the participatory model of heritage management has to be built on mutual trust, respect and cross-level communication, transparency in both plans and action taken on both sides -authorities and community - and constant information sharing (European Union, 2017; European Union, 2018). Properly constructed, the participatory model of heritage management should not have either capacity gaps, incentive gaps, or power gaps (Osmani, 2007). Finally, one more conclusion should be recognized as significant - there is no one model of participatory heritage management that will suit all sites and communities (Häyrynen, 2018). The relative importance of the various factors determining the achievement of the goals set is determined by the local conditions (Irvin and Stansbury, 2004; Abelson and Gauvin, 2006), so every new case study can contribute to raising the overall level of knowledge about the process.

The implementation of participative model offers several heritage-specific benefits (Fig. 1).

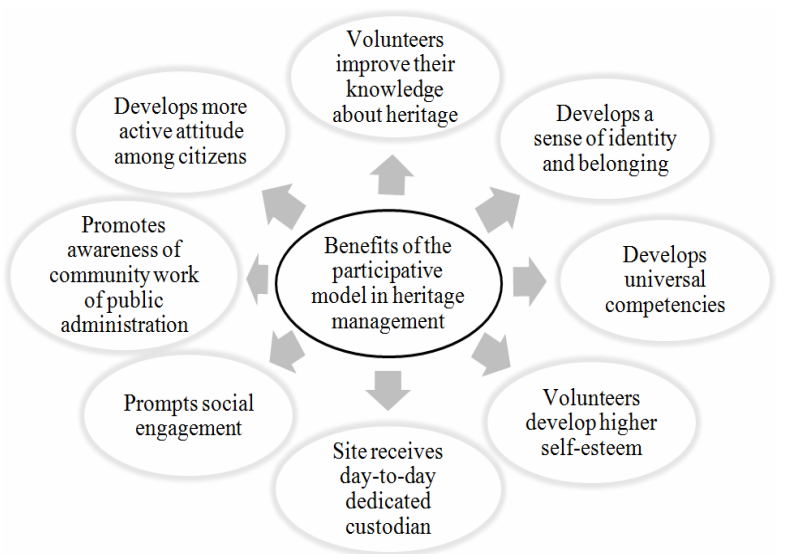

Fig. 1. Benefits of the participative model in heritage management (source: author's own work based on: Lowndes and Sullivan, 2004; Robinson et al., 2005; European Union, 2017; Scheffler, 2017; Historic England, 2018).

The primary benefit to the heritage assets themselves is the fact that with the participatory model a site gains a dedicated, day-to-day guardian. This can assure it better protection from damage or destruction. It is impossible for the public administrative authorities alone to take the necessary care of every site, particularly if an area or town is rich in valuable heritage assets but has limited available personnel. Also, on the practical level, there are other benefits resulting from the participatory model, which are more remote in time, or indirect. For example, community activists can act as diffusers of heritage-related knowledge and values in the local community, and contribute to the formation of the cultural identity of others. The participatory model of heritage management raises awareness of heritage values in society in general, helping both to create a local identity and well-educated social partners; it builds a system of shared responsibilities (Chambers, 2002; Kling, 2010; The Nordic Centre of Heritage Learning, 2012; European Union, 2018) but it can also represent a solution to solve broader problems, such as social exclusion or low selfesteem, and can inspire creativity and change attitudes towards learning (developing a life-long learning approach) (the European Commission, 2009; Birgisdóttir, 2014; Christidou and Hansen, 2015; The Community Volunteering Charity, 2016).

For the local authorities, social engagement brings benefits, but can also incur certain additional administrative costs, for example the costs of the additional decision-making time that this way of working necessitates (Throsby and Rizzo, 2006), especially due to the fact that there is a specific set of values assigned to heritage but a lack of specialized knowledge (Howard, 2003), which can result in inappropriate actions being taken in matters related to heritage assets. Insufficiently supervised cooperation with the community renders authorities unable to monitor the performance of the public entities legally 
responsible for heritage protection, such as the conservation services (Damgaard and Lewis, 2014). This is why one of the key issues in community engagement is who may and should participate, and what criteria experts should take into account in selecting activists to partner with them. This selection has a bearing on the scope of action of the custodians, as well as on the quality of that action (Head, 2007). The adaptation of the participative model to individual circumstances requires the relevant public administrative bodies to be flexible and to interact with their surroundings, from which they have to date tended to be rather isolated (Bourgon, 2007). Such a degree of interaction is a challenge because it generates problems with accountability.

\subsection{Methodology and study area}

Having listed the benefits of developing participative management forms and identified the cultural and social values of heritage, we begin the analysis of the role of CCs with the hypothesis that the community care for heritage sites is a valuable supplement to the core system of heritage protection that works well for both the sites and the public services.

The aim of the article is to identify the factors determining the development of this model. In view of this purpose, the study seeks to give answers to the following research questions: 1) What roles can CCs take on in heritage protection, given the existing Polish regulations, which provide the legal framework for their activity and accountabilities, and the specialised background (knowledge, competencies) required of a $\mathrm{CC}$ to perform those roles reliably and to the advantage of heritage? 2) What problems and threats (and to whom or what?) arise out of the current CC operating format? 3) What could be done/changed/supplemented to develop and optimize the CC format (in Poland and in the broader context)? The factorial analysis was the method used to evaluate what determinants are crucial for the implementation of participative heritage management. In previous empirical studies, most of which were carried out in western and northern European countries, a value-based, descriptive analysis of the factors determining implementation of the participation model was conducted. The factorial analysis method was chosen in view of the nature of the subject under analysis, since assessing the quality and nature of action taken was of greater importance than any quantification of it.

The empirical study profiled in this article looks at the active community custodians of heritage in 11 poviats (districts) in southern Poland (Figure 2): Cracow (the city proper), Greater Cracow (the metropolitan area), and nine other administrative regions with local governments under the jurisdiction of the Voivodship Authority for Heritage Protection in Cracow: Sucha Beskidzka, Myślenice, Wadowice, Oświęcim, Chrzanów, Wieliczka, Olkusz, Miechów and Proszowice.

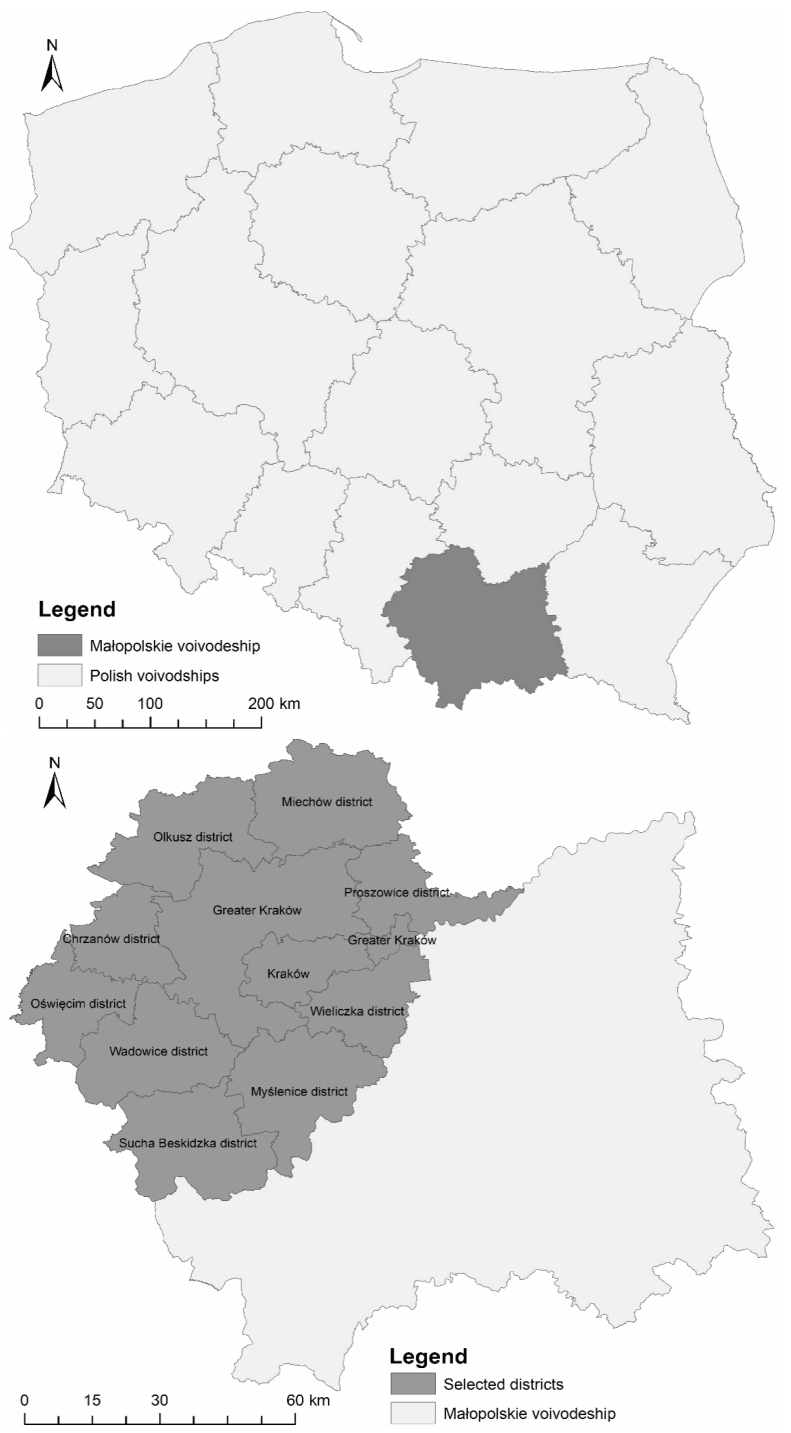

Fig. 2. Geographical region of empirical study.

This authority holds the verification records of procedures for the nomination of CCs, and documents their activity. A total of 95 individuals and one entity (a club run by a residential development council) hold CC status in the region under analysis. They form a diverse group in terms of age (ranging from young adults to senior citizens) and education (for more details see Fig. 2). They variously exercise care and custody of single heritage assets and entire urban plans, and their sites fall into several categories of heritage (industrial, religious, defensive, architectural, etc.). Some community custodians define their area of custodial interest in detail by indicating the period or social group to which the origins of a given asset may be traced. The majority of heritage assets in their care are public property. The rest are privately owned, some of them by religious communities. The majority of structures and sites in the latter, smaller group, however, are 
abandoned, or have lost their owners (for example during WW II), and hence, while formally private, in fact are often neglected. The region selected for this empirical study was chosen for three reasons: the administrative uniformity of its heritage monitoring system; its historically complex and multicultural character (shaped in large measure by the after-effects of World War II and the subsequent changes to its economic structure, which caused many types of sites and structures to lose their original functions); and the diversity of types of heritage in the community custodians' care.

Among the documents analysed for the purposes of this study were the complete administrative records of the CCs' activities held by the Voivodship Authority for Heritage Protection in Cracow for the years 2014-2018 (applications for the award of CC status, reports on joint decisions taken by the authorities and the custodians, action plans drawn up by the custodians, custodians' references, custodians' lists of work performed, documentation (incl. photographs) of their work, and correspondence between poviat authorities and the Voivodship Authority for Heritage Protection). This material is supplemented with surveys obtained from the 11 poviat councils (specifically from employees in the respective departments for heritage and culture) and information given by an employee of the Voivodship Authority for Heritage Protection in Cracow responsible for supervision of the CCs (in interview form). The survey consisted of questions regarding the number of community custodians, the assets they protect, incidents of withdrawal of community custodian status, distinctions awarded to custodians for outstanding work, action taken by the custodians in cooperation with authorities, number of custodians who had submitted reports on their work, and requests from custodians for information on monuments or other professional assistance. The range of sources and methods used to gather data on the participation processes was established in compliance with the OECD recommendations (OECD, 2005). Further information on the $\mathrm{CCs}^{\prime}$ activities was also obtained from media reports and interviews with the CCs (67 items) and by analysing websites maintained by CCs or institutions collaborating with the CCs (42 websites) ${ }^{1}$.

\section{RESULTS AND DISCUSSION}

In respect of the theoretical aspects of the subject under study and the experiences of entities implementing the participatory model in Europe, the following successful measures of implementation were

${ }^{1}$ The author of this study was unable to obtain any further information on the CCs' activities directly from the CCs themselves as their contact details were inaccessible (pursuant to the personal data protection law). Only their names are released to the public. identified: 1). The existence of legal instruments governing community custodians' appointment and work and enabling both them and the public authorities to take measures to enforce heritage protection law; 2). The regulation of cooperation between $\mathrm{CCs}$ and professionals (whether this was incidental or regular in nature; the mode and frequency with which information regarding their mutual expectations, plans and actions was shared between them; whether or not their cooperation was supported with funds for the CCs' work; and how and whether they shared other assets, e.g. space or equipment); and 3). The custodians' suitability for their role in caring for their respective assets (their knowledge and experience).

In order to evaluate the degree and standard of implementation of the above measures on the basis of analysis of the empirical material gathered by the author, the following lists were compiled: types of CCs' activities in the poviats under analysis (Table 1); examples of cooperation between a given $\mathrm{CC}$ and the relevant public institutions (Table 2); the qualifications of CCs in the poviats under analysis (Fig. 3).

\subsection{Legal framework for CCs' actions; authorities' wherewithal for enforcing heritage protection law}

The Polish legal provision for community protection of heritage does have certain strengths, yet, we must emphasize, suboptimal in its present format. The fact that the legal framework regulates only selected (minor) impacts on CCs' work is among the main impediments to their work, and several amendments or additions to the Polish law on community custodianship of heritage would be expedient. Pursuant to the current legal provision, the public administrative authorities can nominate a CC, but have no legal instruments at their disposal to monitor the subsequent activities of the $\mathrm{CC}$. The nature of cultural heritage is such that long-term, sustainable action is vital to the preservation of its cultural and social values, and there should be procedures in place to enable CCs to collaborate with the relevant public administrative bodies within the structure of a mutually acceptable action plan tailored to the needs, legal constraints, technical condition, and other aspects of specific assets.

Under-regulation creates difficulties for both CCs and public authorities (in terms of accountability for outcomes). Public-community partnership clearly needs to be more formalized in respect of the accountabilities of both sides, and should ensure a minimum information flow between the authorities and community activists. There is also an obvious need for a system of reviews of CCs' competencies, especially with regard to those who do not have a formal professional education in heritage and heritage protection. 
Another problem in Poland is the limited scope for meaningful outcomes of action taken by CCs. Their potential for cooperation with institutions responsible for punishing violations of the monument protection law in Poland is also restricted. The nominal authority they wield to admonish owners for both deeds and negligence is in fact a no-action letter because it carries no penal sanctions. A CC may alarm law enforcement or heritage conservation services to prevent the destruction of a site, but this is a right that every citizen in Poland may exercise. Most frequently, the CCs' role consists in reporting undesirable activities to the competent authorities and thus helping bring misconduct to light. However, the difficult situation of conservation services in Poland hampers community protection of heritage. Work overload in government agencies sometimes delays their response to abuses reported by CCs, making the latter feel ignored. Another significant obstacle is the poor enforcement of criminal law in respect of damage to or neglect of heritage sites or structures in Poland. The poor efficiency of law enforcement authorities is reflected by the fact that, for example, CCs often send out notices of incidents occurring on the site to all the public services known to them without first checking which is the one competent to respond in a particular case. The authorities' obligation to reply consumes time and resources that would be better spent carrying out their statutory duties. Sometimes dismissals on the account of lack of territorial jurisdiction are interpreted by CCs as unlawful negligence and lead to accusations of dilatory action being filed with law enforcement agencies. Before the role of CCs can be broadened, profound reform of the system of law enforcement in Poland is necessary.

\subsection{Organization of participatory activities, and relations between authorities and volunteers}

The analysis of the empirical material indicates that CCs' main activities are to collect information and artefacts relating to "their" sites, and promote knowledge about them. This is broadly similar to their role in other European countries. However, it is important to point out that some forms of care of heritage assets are not practiced by CCs in the Polish formula. A prime example of one such shortcoming in this system is the absence of monument "adoptions" engendering legal responsibilities resulting from a formal agreement between the authorities (or owners) and the volunteers. In most cases CCs' activities take the form of discrete, short-term projects rather than long-term initiatives (few were cyclical or repetitive tasks or activities).

Table 1. Types of CC activities in the poviats under analysis (source: author's own work based on source materials (CCs' quarterly and annual reports, CCs' websites and blogs; websites of local authorities and public institutions of culture; interviews with CCs; event ephemera; petitions launched by CCs; formal documents issued by poviat authorities; photographic documentation of CCs' work).

\begin{tabular}{|c|c|}
\hline Activity type & Empirical examples of action \\
\hline $\begin{array}{l}\text { Supervision of } \\
\text { heritage sites }\end{array}$ & $\begin{array}{l}\text { Documentation of thefts from, damages to, and uses of assets that threaten cultural values or existence. } \\
\text { - Documentation of effects of the owner's negligence in ensuring the safety of the heritage asset, reporting of } \\
\text { misconduct during construction work (unlawful failure to conduct archaeological surveys, etc.), notifying the } \\
\text { relevant public services of events, processes, and activities detrimental to the heritage resource. }\end{array}$ \\
\hline $\begin{array}{l}\text { Gathering and } \\
\text { archiving of } \\
\text { heritage data }\end{array}$ & $\begin{array}{l}\text { - Gathering technical documentation. } \\
\text { - Gathering memorabilia and furnishings including items originally connected to the heritage site but later } \\
\text { taken away and sold (repurchasing), or others similar to them. } \\
\text { - Creation of photographic records of the heritage site, which is particularly important for decaying sites (e.g. } \\
\text { inscriptions on historical tombstones), and sharing them with the relevant services and owners. } \\
\text { - Searching through archives, often finding historical information about the site previously unknown to the } \\
\text { owners or conservation authorities. } \\
\text { - Collection of artefacts related indirectly to the site; such collections have potential for use in narrative } \\
\text { exhibitions showcasing the history of military, technical, post-industrial, and other types of sites (e.g. records of } \\
\text { industrial production, operation of railway stations, etc.). } \\
\text { - Creation of oral history archives, which are of fundamental significance for assets and events whose history } \\
\text { can only be recalled by elderly people. }\end{array}$ \\
\hline $\begin{array}{l}\text { Promotional } \\
\text { activities to } \\
\text { stimulate interest } \\
\text { in heritage sites } \\
\text { and encourage } \\
\text { protection }\end{array}$ & $\begin{array}{l}\text { - Organization of lectures; displays of memorabilia or records, including as permanent exhibitions (in churches } \\
\text { or private museums run by CCs). } \\
\text { - Organization of workshops and competitions about heritage sites and their history. } \\
\text { - Contact with the media. } \\
\text { - Blogging on heritage sites. } \\
\text { - Preparation of publications on historical sites and their history - occasionally these may be the only studies on } \\
\text { particular sites, some may be published as guidebooks. } \\
\text { - Running campaigns engaging the community in the care of heritage sites (such as tidying abandoned } \\
\text { cemeteries with schoolchildren), promoting the sites, contributing to intercultural dialogue and respect for } \\
\text { cultural differences (e.g. working with Jewish communities to take care of former Jewish property, promoting the } \\
\text { memory of that culture in Poland, and providing assistance locating graves). }\end{array}$ \\
\hline
\end{tabular}




\begin{tabular}{|c|c|}
\hline & $\begin{array}{l}\text { - Application to authorities to create trails and install heritage signage. } \\
\text { - Promotion of sites of significant value to the community which might otherwise be disregarded by public } \\
\text { authorities. }\end{array}$ \\
\hline Fundraising & $\begin{array}{l}\text { - Organization of fundraising events. } \\
\text { - Filing applications with institutions financing such projects, both public and private. }\end{array}$ \\
\hline $\begin{array}{l}\text { Submission of } \\
\text { heritage-related } \\
\text { applications to } \\
\text { government } \\
\text { agencies }\end{array}$ & $\begin{array}{l}\text { - Filing requests for inscription on heritage lists of sites believed to be of essential cultural value or facing } \\
\text { destruction or demolition (e.g. engineering heritage). } \\
\text { - Filing requests for specific work to be done on a site, e.g. for security or safeguarding purposes, or installation } \\
\text { of storm-water drainage. } \\
\text { - Filing petitions to start debates on heritage issues (contemporary uses, decay, etc.), especially in connection } \\
\text { with resources outside current areas of interest of public institutions. } \\
\text { - Proposing new functions and uses for abandoned heritage sites. }\end{array}$ \\
\hline $\begin{array}{l}\text { Participation in } \\
\text { planning } \\
\text { procedures }\end{array}$ & $\begin{array}{l}\text { - Submitting requests and opinions concerning heritage sites and their surroundings, e.g. to ensure better } \\
\text { exposure (e.g. green areas around military heritage sites). }\end{array}$ \\
\hline $\begin{array}{l}\text { Media } \\
\text { intervention } \\
\text { campaigns }\end{array}$ & $\begin{array}{l}\text { - Alerting the public to acts of prejudice, or constituting a threat to heritage sites, such as investor pressure, } \\
\text { mass tourism, investment projects on heritage sites, or display of advertising degrading the landscape values of } \\
\text { historic districts. }\end{array}$ \\
\hline
\end{tabular}

1. Individuals with specialised knowledge of heritage acquired due to their occupation or education (whether complete or ongoing), such as art and heritage conservators, museum professionals, historians, archaeologists, or culture studies experts
2. Individuals in professions related to heritage assets and involved in processes of heritage use and improvement, such as the construction industry (construction engineers and technicians, architects, landscape architects*) and tour guides

\section{Community custodians of heritage in the study sample}

3. Individuals whose knowledge of heritage developed as a non-professional interest. These often include teachers, academics, councillors, civil servants, and members of NGOs dedicated to saving sites and disseminating knowledge of local heritage
4. Owners or users of heritage sites, such as priests at listed churches, and residents or owners of listed residences

* Some professionals, such as architects or construction industry professionals, fall into the second category rather than the first because the conservation services argue that engineering programmes (in higher education) do not offer sufficient instruction in architectural and art history or art conservation.

Fig. 3. Community custodians of heritage in the study sample (source: author's own work based on source materials (CCs' quarterly and annual reports, CCs' websites and blogs; websites of local authorities and public institutions of culture; interviews with CCs; event ephemera; petitions launched by CCs; formal documents issued by poviat authorities; photographic documentation of CCs' work).

CCs cooperate with public institutions, but it should be stressed that institutional attachment was frequently observed (some CCs, e.g. in Chrzanów or Cracow, cooperate only with a single cultural institution, such as a museum or library, to orchestrate various joint projects). A significant observation is that these are often not the institutions named in the law as the intended partners for CCs (which are the poviat authorities and the Voivodship Authority for Heritage Protection).

Moreover, the public entities cited in the analysis did not recognize CCs as equal partners, and only one of them drew attention in its work to the need to raise public awareness of the existing legal formula governing the work of CCs (Greater Cracow). Most custodians and authorities seem to exist and work in rather different circles, meeting only when joint projects are undertaken. This causes a lack of cohesion in their activities and generates unnecessary costs due to duplicated action. Another conclusion is that there are no extra funds for CCs' activities in public authorities' budgets. The funds for organizing the CCs' work are sourced elsewhere, generally by the custodians themselves. The lack of stability in funding for CCs' action reduces their wherewithal to act.

Since CCs need the support of the public services for their activity, their mutual relations are of critical importance, affecting the conditions for collaboration and coordination of joint actions. In the Polish case, these relations are shaped by both ongoing processes and circumstances (mentioned above) and the historical context. The relationship between the 
community and government agencies is often one of limited trust. Poles have been suspicious of authorities and their motivation and integrity ever since Poland lost its statehood in the late $18^{\text {th }}$ century (the period of the partitions) and again forfeited its sovereignty to the post-World War II Soviet occupation. This cloud hangs over all collaboration projects, which are further hampered by CCs' frequent failure to accept that public administration also has limited human and financial resources. Results of Polish studies from recent years have indicated that Poland has seen a lot of embedded prejudice against the participative model and reluctance to accept it (Chrzanowski and Rościszewska, 2014). This analysis, which sought to examine the $\mathrm{CC}$ operating formula, essentially confirmed those study results: it identified cases of comprehensive collaboration between CCs and public administration, but also crisis situations in their mutual relations. CCs work with a variety of institutions, but they expect public entities to help them meet their needs and objectives (Table 2).

Table 2. Cooperation between CCs and public institutions (source: author's own work based on source materials (CCs' quarterly and annual reports, CCs' websites and blogs; websites of local authorities and public institutions of culture; interviews with CCs; event ephemera; petitions launched by CCs; formal documents issued by poviat authorities; photographic documentation of CCs' work).

\begin{tabular}{|c|c|c|c|}
\hline $\begin{array}{c}\text { Type of } \\
\text { cooperation }\end{array}$ & Example activities & Partners & CCs' role \\
\hline Joint action & $\begin{array}{l}\text { Educational activities and promotion of } \\
\text { local culture (exhibitions, lectures, } \\
\text { workshops, guided tours, elements of regular } \\
\text { programmes promoting heritage). } \\
\text { - Fundraising (to save monuments). } \\
\text { - Scientific research (disseminating and } \\
\text { seeking information and records on specific } \\
\text { sites; cataloguing assets) }\end{array}$ & \multirow{2}{*}{$\begin{array}{l}\text { - Institutions of culture (museums, } \\
\text { libraries, cultural centres). } \\
\text { - Educational institutions. } \\
\text { - Local government authorities } \\
\text { (mayors, borough heads, councillors). } \\
\text { - Science and research institutions } \\
\text { (schools of higher education, institutes, } \\
\text { tourism associations). }\end{array}$} & \multirow{2}{*}{$\begin{array}{l}\text { - Initiator of activities } \\
\text { or collaboration. } \\
\text { - Visitor invited by } \\
\text { public institutions to } \\
\text { cooperate. }\end{array}$} \\
\hline $\begin{array}{l}\text { Resource and } \\
\text { knowledge } \\
\text { sharing }\end{array}$ & $\begin{array}{l}\text { Releasing access to knowledge base, } \\
\text { documents and photographic records } \\
\text { amassed (temporary access, indefinite } \\
\text { transfer, transfer for digitization and } \\
\text { subsequent public access). } \\
\text { - CCs drawing on heritage professionals' } \\
\text { expertise and public records (incl. through } \\
\text { dedicated educational courses for CCs). } \\
\text { - CCs using space and equipment } \\
\text { belonging to public institutions. }\end{array}$ & & \\
\hline $\begin{array}{l}\text { Financial } \\
\text { support }\end{array}$ & $\begin{array}{l}\text { Participation in national and regional } \\
\text { programmes run by public institutions of } \\
\text { heritage (such as heritage accessibility } \\
\text { programmes, events promoting monuments, } \\
\text { etc.). }\end{array}$ & $\begin{array}{l}\text { - Ministry of Culture and National } \\
\text { Heritage. } \\
\text { - Institute of National Remembrance. } \\
\text { - Małopolska Voivodship Government, } \\
\text { National Institute of Heritage. }\end{array}$ & $\begin{array}{l}\text { Implements part of } \\
\text { programme. }\end{array}$ \\
\hline
\end{tabular}

Their choice of entity depends on specific interests, profile of the public institution, and type of site under protection. CCs work with small local institutions as well as with entities with leading roles in regional, national, or global heritage and history, such as the Auschwitz-Birkenau Museum.

It is important to note that while the Act designates Voivodship Heritage Conservators and poviat councils as the principal partners for CCs, the questionnaires sent out to poviat councils showed that these institutions had not been approached by CCs either for information on heritage sites or for professional assistance. The CCs sought cooperation with specialized local government agencies, primarily institutions of culture, more than with the authorities. This indicates that legal provisions are out of touch in the actual custodian practice. Cooperation at the level of the authorities mostly boils down to financing CCs' activities. Only one local government (Greater Cracow) was found to have included CCs in their local programmes for heritage protection, pointing up their role in heritage care. Moreover, the same poviat published brochures promoting the $\mathrm{CC}$ concept. It is also important to note that CCs carry out their activities not only in collaboration with public institutions; other partner entities include numerous local and transregional associations, religious and scouting organizations, and other members of local communities (volunteers) inspired into acting.

As mentioned above, the information received on the sample region under analysis disclosed hurdles to cooperation between $\mathrm{CCs}$ and the authorities. Though these were occasional, they bear out the complexity of the relationships between the public administration and a society demanding to exercise its right to participate. The historical and contemporary Polish circumstances that have stunted the development of those relations combined in the period 
under analysis to produce a cumulative effect in the Chrzanow poviat. The local government authorities there argued that the $\mathrm{CCs}$ in their region lacked experience in care of heritage owing to their youth and unfinished education (though analysis of records of their activities carried out for this article proves that the CCs had significant achievements documented by references from the many institutions that these individuals worked with) and acted for their own profit (which was another claim unsubstantiated by the records analysed). In their justification for refusing to work with these social activists, the local authorities maintained that their conduct was too emotional, they were uncritical in their opinions, and unmindful of the legal and physical constraints on public institutions. This example appears classical for the morphology and etymology of conflicts between CCs and the public administration. On the one side we see enthusiasm, the urge to act, and accusations of misguided action or neglect in heritage protection on the part of the public administration in the past (a common approach in the media), and on the other hand there are the constraints to the operation of the public administration in Poland. These facts warrant the conclusion that in this particular case there was no evidence of a desire to seek compromise or to offer explanations as to why certain CCs' activities were unsuitable and what made their expectations unrealistic. There was no open debate on mutual expectations and opportunities for collaboration.

The analysis also found that the conflicts between the activists and the authorities often stemmed from different perceptions and priorities regarding the cultural and economic values of the sites, especially assets and sites in poor technical condition not representing a heritage type of prime importance for the region's economy or history. According to CCs' declarations, their eagerness to be involved in heritage protection is value-driven. The values they most commonly cited as important were the symbolic, the spiritual, and the social. Historical values and quality of authenticity were considered an element of social history. In some cases aesthetic values were also cited, but these were clearly secondary to the others. The CCs value "their" assets for their cultural merits, including their uniqueness, such as railway infrastructure or postmilitary sites. Faced with operating constraints, public administrative bodies focus on sites of high historical or aesthetic merit and heritage of global or national significance. Communities tend to prefer a focus on assets of social significance that have made a mark on the local identity. Some CCs emphasize heritage values that are utilitarian rather than historical, for example eagerly taking care of facilities that have gained popularity as social venues. They notify the authorities of community expectations surrounding sites of remembrance (e.g. in one case they are fighting for a war cemetery to be renovated and formally recognized as a World War I commemorative site. They consider this a better solution than the site officially designated by the local authorities, namely a plaque in a different location, because it stirs social emotions.

\subsection{CCs' knowledge and experience}

Conservation professionals have expert knowledge of the origins and history of heritage sites, acquired through formal education, and this helps them attribute commensurate value to assets, especially those of historical, artistic, and aesthetic significance. Community activists' knowledge is linked to the social and cultural values of a site and its associated emotional load, content, and connotations. It is built and broadened as a result of their own studies, and as such it requires verification by experts (based on documentation or interviews). Candidates' competencies and motivation should also be probed, and their activity plans examined. The candidates for the award of CC status included in this study sample were grouped according to the criteria proposed in Fig. 4. While simple verification of their core knowledge was sufficient for those in the first group (who had documented specialized degrees), the Voivodship Authority for Heritage Protection had to investigate the actual competencies of candidates from the second, third and fourth groups in detail. These candidates were required to submit references and evidence of their previous activities documenting their knowledge, such as projects carried out, publications written, and/or records of their activity. Public authorities also evaluated each candidate's level of involvement and reasons for their engagement in heritage protection issues.

It is important to note, however, that the law only requires community activists to be verified at the stage of their application for CC status. Public services do have the authority to revoke this status at a later stage, but this hardly ever happens in practice, with only isolated instances reported nationwide. The current regulations do not require $\mathrm{CCs}$ to take any examinations or undergo any other form of verification in the field of heritage or legal issues relating to the use or protection of heritage, though some public institutions do request this.

Under the current law, a CC is obliged to report periodically on their activities, though in the sample under analysis, reports were in fact filed only by $16 \%$ of CCs. This was doubtlessly an oversight, but one that nevertheless indicates poor monitoring of $\mathrm{CCs}$ ' activities by the public services, whereas stricter control might help rectify instances of misconduct by CCs should the services find evidence of irresponsible or damaging action or inaction. Also, it seems likely that some CCs are not doing anything in the benefit of 
"their" site, as they do not release reports or make public statements, and do not give accounts of their activities in the media.

For community activists to achieve their objectives they need to be aware of the legal constraints binding them as CCs, and of the actions that the public services can take. The level of this awareness is far too poorly verified. It is possible to check if a candidate knows their way around the regulations governing their activity, yet it is hard, if not impossible, to probe their knowledge of the realities of the work of the public administration, a qualification that could help minimize conflict situations and unrealistic expectations towards these institutions.

Any involvement in heritage protection requires at least a modicum of knowledge of the field or the effort will prove pointless if not detrimental. Due to poor understanding of the legal and organizational constraints on the operations of public entities, some CCs' activities actually generate excessive costs and consume processing capacity to no effect (for example, reporting of misconduct to the wrong authorities, or reporting of what are in fact non-existent or exaggerated problems). Likewise, unauthorised work carried out on a heritage asset - such as work that the CC considers necessary for the security of an asset but which should not be performed without the proper qualifications, or unauthorised interventions on private property- can often cause irreversible damage. What compounds the situation is that the law as it stands does not require CCs to report on their activities, which means that the authorities cannot always react promptly in the event of harm caused by the CC's conduct.

The administrative authorities check the qualifications of a candidate for the $\mathrm{CC}$ status to the extent allowed by law and within the actual capabilities of their staff. The evidence suggests, however, that a broadening of the scope of this screening process would be expedient. Nonetheless, if a system of examinations for CCs were to be introduced, it would have to incorporate the recognition of varying levels of competencies: higher among those with heritagerelated degrees and lower for those whose formal qualifications are limited to training courses. Presumably, then, this would also mean that the scope of activity open to each CC would vary according to their qualifications. However, regardless of their level of competence it should be mandatory that their activity be supervised by experts. Such supervision should be broader when a CC has no professional heritage-related training. The law should be more explicit with respect to mandatory training and exams. There should be a form of compulsory studium generale for all $\mathrm{CCs}$, covering fundamental heritage knowledge, with a subsequent requirement for regular upgrading of qualifications specific to the character of the site the person looks after. Ideally, the legal system should be altered so as to encourage the public services to screen community activists to identify the best of them as formal partners.

When reviewing candidates' qualifications for the role of $\mathrm{CC}$, public services should also take into account their "soft", less formally classifiable skills and experience. Community representatives have better insight into both the emotions evoked locally by particular heritage assets and the social expectations as to its use. Cooperation between administrative bodies and society yields commensurable outcomes in this area and helps investigate the social needs of the successors to a resource. In this respect CCs become advocates of the local community. Their emotional attitude to heritage was often evident in the records analysed. CCs write of responsibility for the resource and its preservation for future generations. Social engagement in the protection of a heritage asset of less objective value offers a chance for it to be preserved, and for memories and artefacts outside museums' fields of interest to be salvaged.

\section{CONCLUSIONS}

The factors determining the functioning of participative heritage management constitute a connective system in which one factor determines another. Every case study therefore brings new observations to bear on the relations within that system. Unfortunately, in Poland, due to the current lack of institutional, long-term cooperation between the relevant authorities and volunteers, and the lack of any frequent and formal reporting of CCs' actions, there are very limited possibilities for any more precise assessment of the factors and effects of their cooperation. Nonetheless, some important conclusions may be drawn regarding the current legal and organizational framework governing heritage volunteering arrangements.

According to the results of previous research cited in the theory section above and the outcomes of the analysis profiled in this paper, one firm conclusion may be drawn - CCs' involvement reinforces the following aspects of heritage protection:

a). Heritage assets - CCs' familiarity with the local context, history, and surroundings of the asset and the local community is superior to that of the public administrative authorities, and it is reinforced by personal attachment. CCs almost always live or are active in the neighbourhood of the heritage site, and its social and cultural values are what inspire them to action. The study also reveals clearly these activists' special interest in heritage testifying to the multicultural history of their respective regions (history that is no more, with dilapidated monuments its only vestiges). Moreover, since the choice of the asset or 
assets they care for is entirely the CCs' their decisions are presumably dictated by one or both of the following considerations: (i) the asset is of supreme importance to the CC; (ii) the asset is at great risk, whether due to human acts or negligence or due to the natural conditions.

b). The local community - CCs contribute to the preservation of cultural heritage and to the historical and heritage education, which is one of the foundation pillars of the local cultural identity. Collaboration between CCs and authorities furthers the cultivation of a civil society. It also helps to improve the dissemination of information on opportunities to engage in heritage care throughout society: CCs often admit that they were prompted to apply for this status by others who already held it and encouraged public involvement, or by observing a CC in action. What is more, CCs network contributes to the creation of an informal environment of mutual assistance and experience sharing.

c). The public authorities - Investigation of the legal status of the public conservation services revealed that their organizational and financial capacity is limited and they have insufficient in-house potential or legal support. As such, the support of CCs is a vital contribution to their work. As mentioned, CCs often monitor the condition of an asset on a daily basis, which is impossible for the public services to do across their respective regions. Community custodianship is often extended over heritage sites that are not key resources in the region in the sense that they are not national or global but local heritage. Sometimes community activists are the only people who monitor the condition of such sites. The activities of CCs also further the achievement of other objectives. They promote social inclusion, e.g. in the form of collaboration with penal institutions (involving prisoners performing tasks such as cleaning assets and tidying the surroundings).

d). The community activists themselves - CCs develop their own social competencies, including the key skills of life-long learning as well as their understanding of how the public administration system works.

The case study proves that the Polish system is capable of yielding the benefits observed in the participatory system of heritage management as depicted in the European empirical studies. Nonetheless, some shortcomings in the legal and organizational solutions in place in the Polish system were clear. While in other European systems the stress is first and foremost on long-term cooperation, with clearly stated goals and legal structure, funds, and methods of evaluating activities, many of those substantial elements are entirely or largely absent from the Polish legal regulations governing the work of CCs. The obstacles identified in the cases studied here add arguments in favour of the expediency of the European trends in shaping the participatory system. The Polish system seems incomplete, in need not only of further legal regulations (on organization, funding, and evaluation), but also of reformulation of the culture of cooperation between society and the authorities. Improving these elements would probably benefit both parties -the authorities and the community custodians -giving them better insight into the needs, competencies, and actions of their partners.

This examination of the Polish system also highlights the danger of cumulative restrictions on the development of the participatory system. It is clear that when legal and organizational solutions offer no room for social initiatives to grow, the importance of historical prejudices grows disproportionately. On the other hand, in several Polish case studies a wide range of various actions were identified that are similar in type and scope to those developed in other European countries. Polish community custodians have similar ideas to their counterparts elsewhere in Europe, which to the author's mind is a function of assignation of the same catalogue of values to heritage. Only a minority of actions are less in evidence (formal adoption of monuments, and long-term functional changes to assets). Unfortunately, CCs' aspirations are limited by the deficiencies in their cooperation with institutions and the lack of a stable funding base for their activities. However, it is important to add that in Poland both parties must share the responsibility for this deficient cooperation. Authorities do not make optimum use of the potential of social activists, but it is also the case that activists rarely submit ideas or inquiries to the authorities. If CCs do make contact with the authorities, it is often to present ready ideas with the hope of obtaining support for their implementation rather than to initiate discussions on long-term resource management.

Summing up, while the analysis conducted for this article partly confirms the initial hypothesis, it does demonstrate that certain legal, formal, organizational, and social requirements remain to be satisfied if the social concept discussed is to work fully effectively. Community care for heritage boosts the chances for long-term, sustainable exploitation of heritage sites. However, this care must be subject to adequate regulation, supervision, and verification. An important and disturbing shortcoming in the system for monitoring CCs' actions is the lack of a system for thorough examination of CCs' knowledge and social competencies. Authorities also need to change their attitude towards volunteers; there is a need for greater open-mindedness to CCs' actions, acceptance of the new forms and ideas that they bring to heritage management, but at the same time brooking no compromises on the good practices in heritage management that should be known to and applied by every professional. The legal solution currently in place 
in Poland does not guarantee optimum fulfilment of the above requirements.

\section{REFERENCES}

Abelson J., Gauvin F-P. (2006), Assessing the Impacts of Public Participation: Concepts, Evidence and Policy Implications. Research Report P|06. CPRN Inc. URL: http://www.ipea.gov.br/participacao/images/ pdfs/abelson\%20and\%2ogauvin_assessing\%2opp\%20i mpacts_2006.pdf. Accessed on 17.01.2019.

Ashworth G. J. (1994), From History to Heritage From Heritage to Identity. In: Ashworth G. J., Larkham P. J. (eds.) Building a New Heritage: Tourism Culture and Identity in the New Europe, First Edition, Routledge, London, 13-30. ISBN: 0415079314.

Bauer Ch., Alaerts L., Van Dessel J., Wouters R. (2011), AQUEDUCT - Acquiring Key Competences through Heritage Education. Landcommanderij Alden Biesen. Bilzen. URL: https://www.yumpu.com/en/ document/read/9498705/acquiring-key-competencesthrough-heritage-education-aqueduct. Accessed on 23.02.2019.

Birgisdóttir B. B. (2014), A New Perspective on Life: Unemployment and the Benefits of Heritage Learning Outcomes. In: Christidou D. (ed.) Implementing Heritage Learning Outcomes, Fornvårdaren 37, Jamtli Förlag, Östersund, 54-63. ISBN: 978-91-7948-252-7.

Bourgon J. (2007), Responsive, responsible and respected government: towards a New Public Administration theory. International Review of Administrative Sciences, 73(1), 7-26. DOI: $10.1177 / 0020852307075686$.

Chambers D. (2002), Volunteers in the Cultural Sector. Institute for Volunteering Research. London. URL: http://nckultur.org/wp-content/uploads/2014/ 10/Survey-rapport_final.pdf. Accessed on 3.04.2019.

CHCfE Consortium (2015), Cultural Heritage Counts for Europe. First Edition. International Cultural Centre. Cracow. URL: https://www.europanostra.org/ourwork/policy/cultural-heritage-counts-europe/.

Accessed on 3.04.2019.

Christidou D., Hansen A. (2015), Pride, Joy and Surpluls Value. Volunteers in Museums in Denmark, Sweden and Norway: A Comparative Report. NCHLC. Östersund. URL: http://nckultur.org/wp-content/uploads /2014/10/Survey-rapport_final.pdf. Accessed on 3.04.2019. Chrzanowski O., Rościszewska E. (2014), Zarządzanie partycypacyjne. Angażowanie społeczności (Participative Governing. Engaging the Society). Zeszyt Partycypacji Publicznej, 2/2014. FISE. Warszawa (Report in Polish). URL: https://partycypacjao bywatelska.pl/wp-content/uploads/2015/o6/1_

zeszytpp_1_2_fise.pdf. Accessed on 17.01.2019.

Council of Europe (2005), Framework Convention on the Value of Cultural Heritage for Society. Faro, 27.X.2005. Council of Europe Treaty Series - No. 199.
URL: https://rm.coe.int/1680083746. Accessed on 2.04.2019.

Damgaard B., Lewis J. M. (2014), Accountability and citizen participation. In: Bovens M., Godin R.E., Schillemans T. (eds.) The Oxford Handbook of Public Accountability, First Edition, Oxford University Press, Oxford. ISBN: 9780199641253. DOI: 10.1093/ oxfordhb/9780199641253.013.0020.

European Commission (2009), The Impact of Culture on Creativity, A Study Prepared for the European Commission. URL: http://www.keanet.eu/ docs/impactculturecreativityfull.pdf. Accessed on 31.01.2018.

European Union (2017), Citizen engagement in the protection of cultural heritage. A policy brief from the Policy Learning Platform on environment and resource efficiency. URL: https://www.interregeurope.eu/ fileadmin/user_upload/plp_uploads/policy_briefs/201 7-23-08_TO_6_Cultural_heritage_and_engagement. pdf. Accessed on 5.03.2019.

European Union (2018), Participatory Governance of Cultural Heritage, Report of the OMC Working Group of Member States' Experts, European Agenda for Culture Work Plan for Future 2015-2018. Publications Office of the European Union. Luxembourg. ISBN: 97892-79-67396-2. DOI: 10.2766/984757.

Fristrup T., Kling S., Sonne L., Zipsane $\mathbf{H}$. (2012), Heritage Learning Outcomes in the Nordic and Baltic Area. NCHL. Östersund. ISBN: 91-87276-364. URL: http://nckultur.org/wp-content/uploads/2014/ 03/HLO-publikation.pdf. Accessed on 7.03.2019.

Graham B., Howard P. (2012), Heritage and Identity. In: Graham B., Howard P. (eds.) Heritage and Identity, Second Edition, Ashgate, FarnhamBurlington, 1-18. ISBN: 978-0-7546-4922-9.

Häyrynen M. (2018), Cultural Heritage and Participatory Governance. In: Halme A-M., Mustonen T., Taavitsainen J-P., Thomas S., Wei A. J., Heritage is ours. Citizens Participating in Decision Making, Europa Nostra, Luxembourg, 12-17. ISBN 978-952-94-0181-9 (PDF). URL: https://www.europanostra.fi/en/heritageis-ours-citizens-participating-in-decision-making/.

Accessed on 25.03.2019.

Head B. W. (2007), Community Engagement: Participation on Whose Terms? Australian Journal of Political Science, 42(3), 441-454. DOI: 10.1080/10361140701513570.

Heritage Protection and Care Act of 23 July 2003. Historic England (2018), Heritage and Society. Part of "Heritage Counts" Report. URL: https:// historicengland.org.uk/research/heritage-counts/ heritage-and-society/. Accessed on 11.03.2019.

Howard D. (2009), Historic Landscapes and the Recent Past: Whose History? In: Gibson L., Pendlebury J. (eds.) Valuing Historic Environments, First Edition, Ashgate, Farnham-Burlington, 51-65. ISBN: 978-07546-7424-5. 
Howard P. (2003), Heritage. Management, Interpretation, Identity. First Edition. Continuum. London-New York. ISBN 0-8264-5897-1.

Irvin R. A., Stansbury J. (2004), Citizen Participation in Decision Making: Is It Worth the Effort? Public Administration Review, 64(1), 55-65. DOI: /10.1111/j.1540-62 10.2004.00346.x.

John P. (2001), Local Governance in Western Europe. First Edition. Sage. London. ISBN: 0-7619-5636-0.

Klamer A., Zuidhof P-W. (1998), The Values of Cultural Heritage: Merging Economic and Cultural Appraisals. In: Economics and Heritage Conservation, The Getty Conservation Institute, Los Angeles, 23-61. URL: https://www.getty.edu/conservation/publications _resources/pdf_publications/pdf/econrpt.pdf.

Accessed on 17.02.2019.

Kling S. (2010), Assessing Heritage Learning Outcomes. How Do We Do It - and Why? Heritage, Regional Development and Social Cohesion International Conference. Östersund. URL: https://relevantmuseum. files.wordpress.com/2013/10/kling-sofia-assessingheritage-learning-outcomes-how-do-we-do-it-e28093and-why.pdf. Accessed on 17.02.2019.

Kooiman J. (1993), Social-political governance: Introduction. In: Kooiman J. (ed.) Modern Governance, First Edition, Sage, London, 1-8. ISBN: o-8039-8890-7. Lowndes V., Sullivan H. (2004), Like a Horse and Carriage or a Fish on a Bicycle: How Well do Local Partnerships and Public Participation go Together? Local Government Studies, 30(1), 51-73. DOI: 10.1080/0300393042000230920.

Macdonald S. (2011), Leveraging Heritage: PublicPrivate, and Third-Sector Partnerships for the Conservation of the Historic Urban Environment. In: Heritage Driver in Development, ICOMOS $17^{\text {th }}$ General Assembly. ICOMOS, Paris, 893-904. URL: https://pdfs.semanticscholar.org/3fd1/odo2dob48345 be46362fef481ff43ff1302f.pdf?_ga=2.118124042.26633 4971.1577535736-1949922788.1575040833. Accessed on 12.03.2019.

Mannarini T., Talò C. (2013), Evaluating public participation: instruments and implications for citizen involvement. Community Development, 44/2, 239-256. DOI: $10.1080 / 15575330.2012 .683799$.

OECD (2005), Evaluating Public Participation in Policy Making. OECD Paris. DOI: https://dx.doi.org/10.1787/9789264008960-en.

Osmani R. (2007), Participatory Governance: An Overview of Issue and Evidences. 7th Global Forum on Reinventing Government Building Trust in Government. The United Nations Department for Economic and Social Affairs. New York. URL: http://uir.ulster.ac.uk/11274/1/Participatory_Governa nce_for_Efficiency_and_Equity.pdf. Accessed on 14.02.2019.

Pendlebury J. (2015), Heritage and Policy. In: Waterton E., Watson S. (eds.) The Palgrave Handbook of Contemporary Heritage, First Edition, Palgrave Macmillan, Hampshire-New York, 426-441. ISBN: 9781-137-29355-8. DOI: 10.1057/9781137293565.

Purchla J. (2012), Cultural heritage and social capital. In: Galusek $Ł$. (ed.) The $1^{\text {st }}$ Heritage Forum of Central Europe, First Edition, International Cultural Centre, Cracow, 69-77. ISBN 978-83-89273-96-3.

Robinson F., Shaw K., Davidson G. (2005), On the side of the Angels': Community involvement in the governance of neighbourhood renewal. Local Economy, 20(1), 13-26. DOI: 0.1080/0269094042000313584.

Scheffler N. (2017), Community involvement in Urban Heritage. In: Göttler M., Ripp M. (eds.) Community Involvement in Heritage Management Guidebook. OWHC, 14-21. URL: http://openarchive.icomos.org/1812/1/FINAL_OWHC \%20Guidebook\%202017.pdf. Accessed on 24.02.2019.

Smith L. (2006), Uses of Heritage. First Edition. Routledge. London-New York. ISBN: 0-203-60226-9 (ebk).

Stebbins R. (2015), Serious Leisure: A Perspective for Our Time. Second Edition. Transaction Publishers. New Brunswick-London. ISBN: 0-7658-0363-1.

The Heritage Council (2000), Policy Paper on Heritage Awareness in Ireland. Policies and Priorities for the National Heritage. The Heritage Council of Ireland Series. ISBN: 1-901137-22-8. URL: https://www.heritagecouncil.ie/content/files/policy_p aper_heritage_awareness_ireland_200o_2mb.pdf.

Accessed on 4.04.2019.

The Nordic Centre of Heritage Learning (2012), Heritage Learning Outcomes in the Nordic and Baltic Area Competence Development among Adults at Archives and Museums. URL: http://nckultur.org/wpcontent/uploads/2014/o3/HLO-publikation.pdf.

Accessed on 30.03.2019.

The Community Volunteering Charity (2016), The Conservation Volunteers. Join in, Feel Good, Doncaster (brochure).

Throsby D. (2002), Economics and Culture. First Edition - reprint. Cambridge University Press. Cambridge. ISBN: 0-521-58406 X.

Throsby D., Rizzo I. (2006), Cultural heritage: economic analysis and public policy. In: Handbook of the economics of art and culture, Vol. 1, Elsevier, Amsterdam, 983-1016. ISBN: 9780444508706.

United Nations (2017), New Urban Agenda, Quito. ISBN: 978-92-1-132731-1. URL: http://habitat3.org/ wp-content/uploads/NUA-English.pdf. Accessed on 29.03.2019.

Vahtikari T. (2019), Report on the Symposium Horizons for Heritage Research - Towards a Cluster on Cultural Heritage, Covent Garden Symposium, Brussels. URL: https://www.reach-culture.eu/wpcontent/uploads/2019/o5/Horizons-for-HeritageResearch-Towards-a-Cluster-on-Cultural-HeritageSymposium-Report.pdf. Accessed on 14.04.2019. 
Zipsane H. (2012), THROUGH heritage as opposed to learning ABOUT heritage! Untraditional Creative Partnerships - Seven Wonders of Arts and Culture in Education. Education and Learning Workgroup, The
European Commission. URL: http://www.housefor culture.eu/upload/Docs\%20ACP/UNTRADITIONALC REATIVEPARTNERSHIPS2012formated.pdf. Accessed on 12.02.2019. 